\title{
Isolation and properties of a substance from the diatom Phaeodactylum tricornutum which induces spawning in the sea urchin Strongylocentrotus droebachiensis
}

\author{
Michel Starr ${ }^{1, *}$, John H. Himmelman ${ }^{1}$, Jean-Claude Therriault ${ }^{2}$ \\ ${ }^{1}$ GIROQ (Groupe interuniversitaire de recherche océanographique du Québec) and Département de biologie, Université \\ Laval, Québec, Québec, Canada G1K 7P4 \\ ${ }^{2}$ Institut Maurice-Lamontagne, Division d'océanographie biologique, Ministère des Pêches et des Océans, C. P. 1000, \\ Mont-Joli, Québec, Canada G5H 3Z4
}

\begin{abstract}
A substance extracted from the diatom Phaeodactylum tricornutum which triggers spawning was characterized, using spawning bioassays of sea urchin Strongylocentrotus droebachiensis to ascertain its presence. Of 14 extraction techniques applied to $P$. tricornutum cells, only alkaline hydrolysis with $1 \mathrm{~N} \mathrm{NaOH}$ extracted the spawning inducer. Ethanol, distilled water, dilute $\mathrm{HCl}$, aqueous $\mathrm{Na}_{2} \mathrm{CO}_{3}$, chloroform/methanol $(2: 1, \mathrm{v} / \mathrm{v})$, acetone, phosphate buffer, anhydrous ether and hexane did not extract the inducer from phytoplankton cells. Once extracted the spawning inducer has a molecular weight between 1200 and 3500 daltons, and is soluble in distilled water, partially soluble in ethanol and methanol and insoluble in chloroform. Only a slight loss in activity occurred over $16 \mathrm{~d}$ when the neutralized $\mathrm{NaOH}$ extract was refrigerated at $5^{\circ} \mathrm{C}$ in darkness. The spawning inducer in the acidified (pH 2.0) aqueous extract can be further extracted with anhydrous ether. After partial purification, this fraction contained a yellowish pigment(s) which strongly absorbed ultraviolet light and reacted with a mixture of equal volumes of $1 \%$ ferric chloride and $1 \%$ potassium ferricyanide, a characteristic of phenolic compounds. The spectral properties of this pigment(s), notably an absorption peak around 260 to $266 \mathrm{~nm}$, resemble those of yellow substances released from a variety of algae. Female sea urchins spawn more rapidly when treated with sperm suspension in addition to extract containing the spawning inducer, indicating that sperm has a synergistic effect on the response. This interaction might have important implications for the synchrony of spawning within invertebrate populations.
\end{abstract}

\section{INTRODUCTION}

Phytoplankton release a substantial component of their photoassimilated carbon into the environment (Nalewajko \& Schindler 1976, Mague et al. 1980, Chrost \& Faust 1983, Fogg 1983, Myklestad et al. 1989). Many reviews suggest that these extracellular products may play an important role in aquatic ecosystems (Hellebust 1974, Fogg 1983). For example, these compounds may influence phytoplankton succession (Pratt 1966, Maestrini \& Bonin 1981, Lewis 1986). Most of the released material thus far described consists of simple

\footnotetext{
- Present address: Institut Maurice-Lamontagne, Division d'océanographie biologique, Ministère des Pêches et des Océans, C.P. 1000, Mont-Joli, Québec, Canada G5H 3 Z4
}

compounds such as organic acids, amino acids and carbohydrates. However, higher molecular weight compounds have also been shown to play a role in phytoplankton interactions (Uchida 1977, Pintner \& Altmeyer 1979).

Recent experimental studies show that compounds released by various phytoplankton species stimulate spawning in the blue mussel Mytilus edulis L. and the green sea urchin Strongylocentrotus droebachiensis O. F. Müller (Starr et al. 1990). This would allow animals to couple their larval phase with phytoplankton blooms. The close coupling between phytoplankton blooms and gamete release for numerous species in different taxonomic groups (Thorson 1946, Himmelman 1975, 1981, Falk-Petersen 1982) suggests that this phenomenon is widespread among marine inverte- 
brates. The synchronization of spawning with phytoplankton blooms should ensure an abundant food supply for planktotrophic larvae, as well as reduced larval mortality due to predation and other environmental factors (Starr et al. 1990).

Many attempts have been made to determine how invertebrate reproductive cycles are coordinated with environmental conditions and, for several echinoderms, photoperiod has been suggested as the factor largely responsible for synchronizing gametogenic events (Pearse et al. 1986). However, in many invertebrates gonadal maturation is completed well before spawning and this suggests that an additional signal is required to stimulate the release of gametes. For many years, physical factors, such as changes in temperature, salinity, light and water movement, have been emphasized as potential spawning cues (Giese \& Kanatani 1987). However, most of these proposed cues are speculative, there being a lack of experimental studies. Thus, environmental changes have often been documented during spawning in the field but it is usually unknown whether the same change of a given factor will provoke spawning when other conditions are maintained constant. One factor which has been identified as a spawning cue for several invertebrates, based on both correlative and experimental evidences, is the spring bloom of phytoplankton (Starr et al. 1990). Starr et al. (1990) suggest that phytoplankton is probably a more reliable signal for spawning than abiotic factors, because it integrates numerous factors affecting larval success. The identification of the spawning inducer(s) from phytoplankton is needed to improve our understanding of the mechanisms synchronizing reproductive events in the natural environment. Further, this spawning inducer may become a useful tool for the aquaculture industry.

The present paper describes the partial purification and characterization of a spawning inducer extracted from cultured cells of the diatom Phaeodactylum tricornutum. Using bioassays of spawning by the sea urchin Strongylocentrotus droebachiensis to monitor the presence of the spawning substance during a variety of purification procedures, we describe a technique which purifies it to a high degree. Since sperm release can also stimulate spawning (Starr et al. 1990), and because physiological responses to chemical signals can be positively modulated by natural compounds, we further examine whether sperm acts as a modulator.

\section{MATERIALS AND METHODS}

Collection of sea urchins. Experiments were performed with sea urchins Strongylocentrotus droebachiensis, measuring 35 to $45 \mathrm{~mm}$ in diameter, collected shortly before natural spawning (late April to early June) in the St. Lawrence Estuary (Québec, Canada) and in Passamaquoddy Bay (New Brunswick, Canada). Prior to the tests, the sea urchins were held in tanks maintained at a temperature of 5 to $8^{\circ} \mathrm{C}$, a salinity of 21 to $24 \%$, and under a $16 \mathrm{~h}$ light: $8 \mathrm{~h}$ dark photoperiod (cool white fluorescent lighting). The seawater contained no phytoplankton and was continuously recirculated through a biological filter. The sea urchins were fed weekly with frozen macroalgae (Fucus vesiculosus and Ascophyllum nodosum).

Phytoplankton cultures. The diatom Phaeodactylum tricornutum Bohlin (obtained from axenic culture at INRS-Océanologie, Rimouski, Canada) was maintained in exponential growth using natural sea water enriched with $\mathrm{f} / 2$ culture medium (Guillard \& Ryther 1962). The $20 \mathrm{l}$ cultures were grown at a temperature of 12 to $16{ }^{\circ} \mathrm{C}$, a salinity of 21 to $24 \%$, and under a $16 \mathrm{~h}$ light: $8 \mathrm{~h}$ dark cycle using cool-white fluorescent tubes as the light source. Air filtered at $0.2 \mu \mathrm{m}$ was continuously bubbled through the cultures. Prior to inoculation, the culture medium was filtered using either a 0.2 um Gelmann cartridge or a Whatman GF/F filter, and autoclaved for $20 \mathrm{~min}$ at $210^{\circ} \mathrm{C}$. Cell densities were maintained between $10^{6}$ and $10^{7}$ cells $\mathrm{ml}^{-1}$ as determined from counts of ca 500 cells using an Neubauer haemocytometer.

Standard bioassay for induction of spawning. A modified version of the spawning bioassays described by Starr et al. (1990) was used to test for the presence of a spawning inducer in different preparations of algal extracts. In each test, 12 sea urchins (previously acclimated for $1 \mathrm{~d}$ at the experimental temperature of 6 to $7^{\circ} \mathrm{C}$ ) were placed individually into glass finger bowls containing $475 \mathrm{ml}$ of $1 \mu \mathrm{m}$ filtered sea water. After ca 1 $\mathrm{h}$, a $25 \mathrm{ml}$ aliquot of algal extract in seawater was added. After $24 \mathrm{~h}$, each sea urchin was transferred to a new finger bowl containing clean sea water and the algal extract was reintroduced. The total number of sea urchins which spawned during the $48 \mathrm{~h}$ bioassay was determined visually. These assays usually were replicated and each sea urchin was only used once.

Preparation of algal extracts. The spawning inducer was extracted directly from phytoplankton cells rather than from the culture filtrate (extracellular products only) since the activity of the inducer seemed to be of short duration in the culture filtrate (Starr et al. 1990). Moreover, the time required to desalt large volumes of sea water would have been prohibitive. The phytoplankton cells were collected on Whatman GF/C filters (pre-combusted at $240^{\circ} \mathrm{C}$ for $24 \mathrm{~h}$ ) and immediately frozen with silica gel at $-70^{\circ} \mathrm{C}$. Fourteen different extraction techniques were applied to phytoplankton cells (see Table 1). Each extract was tested using 12 sea urchins and was prepared from $6 \times 10^{9}$ Phaeodactylum 
tricornutum cells. This quantity of phytoplankton cells, which was sufficient to stimulate spawning in $96 \%$ of mature sea urchins (Table 1; Expt 15), was considered to be one phytoplankton equivalent. Controls for each extract were prepared using filters without phytoplankton and were tested simultaneously with extracts. For each extraction technique, the filters with or without phytoplankton were ground with a Virtis homogenizer. The supernatants were obtained by centrifugation $\left(6000 \times \mathrm{g}\right.$ at $4{ }^{\circ} \mathrm{C}$ for $\left.30 \mathrm{~min}\right)$ and were further clarified by filtration on Whatman GF/F filters which had been pre-combusted at $240^{\circ} \mathrm{C}$ for $24 \mathrm{~h}$. Extracts, with organic solvents and alcohols, were dried using a rotary evaporator at $<40{ }^{\circ} \mathrm{C}$ and suspended in $100 \mathrm{ml}$ of distilled water for the bioassay. Extracts containing distilled water, phosphate buffer, dilute acid, $\mathrm{Na}_{2} \mathrm{CO}_{3}$ and $\mathrm{NaOH}$ were adjusted to $\mathrm{pH} 7.0$ before exposition of the sea urchins. Spawning bioassays were performed immediately following the preparation of extracts.

To determine whether the spawning inducer was also present in macroalgae, extracts were made from epiphyte-free specimens of Fucus vesiculosus L. which had been collected in the St. Lawrence Estuary and frozen at $-10^{\circ} \mathrm{C}$ for $<1 \mathrm{wk}$. Using a mortar, $3 \mathrm{~g}$ of small pieces of fresh algae were ground with Ottawa sand (pre-washed for $24 \mathrm{~h}$ with $0.2 \mathrm{~N} \mathrm{NaOH}$ and rinsed with distilled water). This material was then processed in the same way as the crude phytoplankton extracts. For controls, the extraction technique was applied to Ottawa sand in the absence of algae. The quantity of extracted metabolites from $0.6 \mathrm{~g}$ of wet algae was considered as 1 macroalgae equivalent. As for the phytoplankton equivalent, 12 sea urchins were tested with the macroalgae equivalent.

Solubility of spawning inducer. $\mathrm{NaOH}$ phytoplankton extracts were lyophilized and resuspended in 100 $\mathrm{ml}$ of chloroform, methanol, ethanol or distilled water for $12 \mathrm{~h}$ at 21 to $24{ }^{\circ} \mathrm{C}$. The insoluble material was collected on Whatman GF/F filters, rinsed with the same solvent, and then dried using a jet of gaseous nitrogen. The chloroform, methanol and ethanol soluble fractions were dried in a rotary evaporator at $<40{ }^{\circ} \mathrm{C}$. Both the insoluble and soluble fractions were dissolved in $100 \mathrm{ml}$ of distilled water and used in bioassays to determine the quantity of spawning inducer present. For each solvent, controls were performed using extracts of filters without phytoplankton.

Molecular weight of spawning inducer. The molecular weight (MW) of the spawning inducer in aqueous extracts of Phaeodactylum tricornutum was estimated using dialysis membranes. The membranes had a nominal MW cutoff of 1200 (from Sigma), 3500 and 6000 to 8000 daltons (from Ultrapore). Dialyses were performed for $36 \mathrm{~h}$ in the dark against distilled water (8 times the volume of the extract and renewed 7 times). The spawning activity of the extracts was then compared to extracts maintained for $36 \mathrm{~h}$ under the same temperature and light conditions.

Synergistic effect of sperm. Sea urchins were exposed to the phytoplankton extract and sperm suspension, both separately and together, to determine whether sperm had a synergistic or additive effect on the spawning response. Tests with sperm involved placing a spawning male in the presence of a nonspawning individual. Spawning in males was induced using strong thermal shocks. Each experiment was conducted over a $2 \mathrm{~h}$ period.

Partial purification of spawning inducer. Aqueous extracts of Phaeodactylum tricornutum were partially purified by ultrafiltration (Amicon Corporation ultrafiltration cell, Model 402) using 'Diaflow' ultrafiltration membranes (Amicon Corp.) with a nominal cutoff at 5000 daltons (YM5). Ultrafiltration membranes were cleared of preservative agents by placing them in a $1 \%$ $\mathrm{NaCl}$ solution for $1 \mathrm{~h}$ and then rinsed with distilled water. The ultrafiltration cell was pressurized using gaseous nitrogen (1.0 to $1.5 \mathrm{~kg} \mathrm{~cm}^{-2}$ ) and constant stirring and temperature $\left(8^{\circ} \mathrm{C}\right)$ were maintained during fractionation. For each ultrafiltration, a maximum of $400 \mathrm{ml}$ of aqueous extract was used and the activity of supernatant and ultrafiltrate was determined using bioassays.

Chromatography. The partially purified extract containing the spawning inducer was further characterized by thin-layer chromatography (TLC) on Mn 300 cellulose plates. The plates $(20 \mathrm{~cm} \times 20 \mathrm{~cm})$ were prewashed with a freshly prepared solution of 1-butanolacetic acid-water ( $4: 1: 5$; top layer), dried at room temperature, and activated at $110^{\circ} \mathrm{C}$ for $1 \mathrm{~h}$ prior to application of the samples. The chromatographic chamber, lined with $3 \mathrm{MM}$ chromatographic paper and wetted with developing solvent, was saturated for $1 \mathrm{~h}$ prior to chromatography. Development was carried out in the above solvent system and allowed to move $19 \mathrm{~cm}$ from the bottom of the plate. All chromatograms were replicated at least once.

Chemical analysis. Chlorophyll a content of phytoplankton cells was determined by filtering cultures onto GF/C filters (Whatman), which were immediately extracted with $90 \%$ acetone for $24 \mathrm{~h}$ before pigment determination by the spectrophotometric method of Lorenzen (1967). Dry weights of phytoplankton cells were determined by filtering a known volume of culture onto a previously combusted and weighed Millipore filter. The cells were rinsed with isotonic ammonium formate to remove any sodium chloride adhering to the Millipore filter, and dried for $2 \mathrm{~h}$ at $105^{\circ} \mathrm{C}$ (any residual formate was volatilized; Parsons et al. 1961). 
Nitrogen, carbohydrate, uronic acid, lipid, phenol and spectral properties were monitored throughout the various purification precedures. Carbohydrates were quantified using the phenol-sulphuric acid procedure of Dubois et al. (1956) and expressed as glucose equivalents. Proteins were measured using the fluorescamine method of Bohlen et al. (1973), as modified by Packard \& Dortch (1975), using the BSA standard. Uronic acids were quantified with the modified carbazole reaction of Bitter \& Muir (1962) and expressed as glucuronolactone equivalents. Lipids were estimated using the dichromate method, with palmitic acid as a standard (Kochert 1978). Phenolic compounds were detected on chromatograms using UV light as well as by using a mixture of equal volumes of $1 \%$ ferric chloride and $1 \%$ potassium ferricyanide (Harborne 1973). Spectral analysis of the purified extract was performed in ether, petroleum ether $\left(35\right.$ to $60^{\circ} \mathrm{C}$ ), absolute ethanol and chloroform by scanning from 200 to $800 \mathrm{~nm}$, at a temperature of 21 to $24^{\circ} \mathrm{C}$, using the same solvent as the reference sample.

\section{RESULTS}

\section{Extraction and characterization of spawning inducer}

Most of the aqueous extracts prepared using the 14 techniques applied to Phaeodactylum tricornutum cells did not stimulate spawning more than control extracts (Fisher's exact test, $\mathrm{p}>0.05$; Table 1; Expts 1 to 14). This indicates that induction of spawning by phytoplankton is due to a limited number of compounds. Extracts with ethanol (Expts 1 to 4), chloroform/ methanol and benzene/methanol (Expts 5 \& 6), distilled water (Expt 9), acetone (Expt 10), dilute $\mathrm{HCl}$ (Expt 12) and $\mathrm{Na}_{2} \mathrm{CO}_{3}$ (Expt 13) did not stimulate spawning, indicating that we can rule out low molecular weight compounds, lipids and related compounds, some water-soluble materials, photosynthetic pigments, glucans and organic acids, respectively, as the spawning inducer. Likewise, little or no spawning resulted when sea urchins were treated with extracts made with ether (Expt 7), hexane (Expt 8) or phosphate buffer (Expt 11), although the number of sea urchins being tested was less. The only extract that significantly stimulated spawning was obtained by hydrolysis of $P$. tricornutum cells with $1 \mathrm{~N} \mathrm{NaOH}$ (Expt 14). This extraction method was highly effective, yielding a percent spawning response within $30 \%$ of that obtained with live phytoplankton (Table 1; Expt 15). The fact that alkaline hydrolysis is required to extract the spawning inducer suggests that it is, or is associated with, a macromolecule. After hydrolysis the inducer was highly soluble in distilled water, partially soluble in ethanol and methanol, and insoluble in chloroform (Fig. 1). Thus, whereas the inducer could not be directly extracted from phytoplankton cells using ethanol, it became more soluble in ethanol following hydrolysis. This suggests that the spawning inducer was a more complex molecule prior to hydrolysis.

When the $\mathrm{NaOH}$ extract was dialysed against distilled water for $36 \mathrm{~h}$ in dialysis bags with a nominal cutoff at 1200 daltons (Table 2; Expt 1), there was no loss in its capacity to induce spawning compared to undialysed extract maintained under identical conditions (Expt 4). In contrast, there was a marked loss in activity when the $\mathrm{NaOH}$ extract was maintained in dialysis bags with nominal cutoffs at 3500 and 6000 to 8000 daltons (Expts $2 \& 3$ ). This indicates that the molecular weight of the spawning inducer after alkaline hydrolysis was between 1200 and 3500 daltons.

Whereas the activity of the spawning inducer in the culture filtrate seemed to be of short duration (Starr et al. 1990), at $5{ }^{\circ} \mathrm{C}$ in darkness the neutralized $\mathrm{NaOH}$ extract was stable, there being little loss in activity over $16 \mathrm{~d}$ (Fig. 2). When the neutralized $(\mathrm{pH} 7.0)$ $\mathrm{NaOH}$ extract was exposed to sea urchins, as seen in Fig. 3 for one experiment, spawning occurred within the first hour. Sea urchins which did not spawn on the first day sometimes spawned the second day, but again within $1 \mathrm{~h}$ of adding the extract. The fact that all spawning occurred within the first hour suggests that the inducer deteriorates rapidly under normal bioassay conditions.

The $\mathrm{NaOH}$ extract from the macroalga Fucus vesiculosus also significantly stimulated spawning compared to control tests (Table 3; Expts 1 to 4). However, the spawning response did not appear to be concentration-dependent and was lower than that of phytoplankton extract (Expts 5 \& 6). Other observations also suggested that the spawning inducer was present in macroalgae. For example, the spawning response to $\mathrm{NaOH}$ extracts from Phaeodactylum tricornutum increased when sea urchins had been provided with macroalgae, although only when the macroalgae had been freshly collected (pers. obs.).

\section{Synergistic effect of sperm}

Sperm alone did not induce spawning in sea urchins which had no previous contact with phytoplankton or phytoplankton extracts (Table 4; Expt 4). In addition, sperm in combination with $\mathrm{NaOH}$ extracts $(0.5$ phytoplankton equivalent) did not increase significantly the percentage of sea urchins spawning beyond that of individuals exposed solely to the extract (Fisher's exact test; $p>0.05$; Expts 6 \& 7). However, differences were evident when reaction time (time to the beginning of 
Table 1. Strongylocentrotus droebachiensis. Percentage spawning in sea urchins exposed to various extracts of the diatom Phaeodactylum tricornutum. Each extract was prepared from $6 \times 10^{9}$ cells and exposed to 12 sea urchins. Controls consisted of sea urchins exposed to extracts from filters without phytoplankton. Since there were no differences between replicates, percentage spawning indicated is for the total number of sea urchins tested. Spawning percentages are from bioassays which ran for $2 \mathrm{~d}$, except those in parentheses where the bioassays ran for $1 \mathrm{~d}$

\begin{tabular}{|c|c|c|c|c|}
\hline \multirow{2}{*}{$\begin{array}{c}\text { Expt } \\
\text { no. }\end{array}$} & \multirow[t]{2}{*}{ Description } & \multirow[t]{2}{*}{ Total $\mathrm{N}$; replicates } & \multicolumn{2}{|c|}{ Spawning (\%) } \\
\hline & & & Control & Extract \\
\hline 1. & $\begin{array}{l}\text { Hot } 80 \% \text { ethanol; } 50 \text { min extraction at } 70^{\circ} \mathrm{C} \text { with } 70 \mathrm{ml} \text { of } \\
80 \% \text { ethanol. Repeated at } 20^{\circ} \mathrm{C} \text {. Extracts combined }\end{array}$ & $24 ; 2$ & 0.0 & 20.8 \\
\hline 2. & $\begin{array}{l}\text { Ethanol extract; two } 50 \mathrm{~min} \text { extractions at } 70^{\circ} \mathrm{C} \text { with } 70 \mathrm{ml} \text { of } \\
80 \% \text { ethanol. Repeated at } 20^{\circ} \mathrm{C} \text { and followed by } 1 \text { extraction } \\
\text { with } 70 \mathrm{ml} \text { of } 50 \% \text { ethanol. Extracts combined }\end{array}$ & $12 ; 1$ & 0.0 & 16.7 \\
\hline 3. & $\begin{array}{l}50 \% \text { ethanol extract; } 36 \mathrm{~h} \text { extraction at } 4^{\circ} \mathrm{C} \text { with } 100 \mathrm{ml} \text { of } \\
50 \% \text { ethanol }\end{array}$ & $12 ; 1$ & 0.0 & 11.1 \\
\hline 4. & $\begin{array}{l}80 \% \text { ethanol extract; extraction with } 100 \mathrm{ml} \text { of } 80 \% \text { ethanol, } \\
\text { at } 50^{\circ} \mathrm{C} \text { for } 50 \mathrm{~min} \text { and then at } 4{ }^{\circ} \mathrm{C} \text { for } 24 \mathrm{~h}\end{array}$ & $12 ; 1$ & $(0.0)$ & $(0.0)$ \\
\hline 5. & $\begin{array}{l}\text { Chloroform/methanol extract; successive extractions for } 3 \text {, } \\
12,3 \text { and } 4 \mathrm{~h} \text {, respectively, at } 4{ }^{\circ} \mathrm{C} \text { with } 66.7 \mathrm{ml} \text { of chloroform/ } \\
\text { methanol }(2: 1) \text {. Extracts combined }\end{array}$ & $24 ; 2$ & 4.2 & 10.0 \\
\hline 6. & $\begin{array}{l}\text { Benzene/methanol extract; } 4 \mathrm{~h} \text { extraction at } 4^{\circ} \mathrm{C} \text { with } 66.7 \mathrm{ml} \\
\text { of benzene/methanol }(4: 1) \text {. Repeated for } 2 \mathrm{~h} \text {. Extracts com- } \\
\text { bined }\end{array}$ & $22 ; 2$ & 0.0 & 4.6 \\
\hline 7. & $\begin{array}{l}\text { Ether extract; two } 1 \mathrm{~h} \text { extractions at } 20^{\circ} \mathrm{C} \text { with } 100 \mathrm{ml} \text { of } 100 \% \\
\text { ether. Extracts combined }\end{array}$ & $12 ; 1$ & $(0.0)$ & $(16.7)$ \\
\hline 8. & $\begin{array}{l}\text { Hexane extract; two } 1 \mathrm{~h} \text { extractions at } 20^{\circ} \mathrm{C} \text { with } 100 \mathrm{ml} \text { of } \\
100 \% \text { hexane. Extracts combined }\end{array}$ & $12 ; 1$ & $(0.0)$ & $(0.0)$ \\
\hline 9. & $\begin{array}{l}\text { Distilled water extract; } 36 \mathrm{~h} \text { extraction at } 4^{\circ} \mathrm{C} \text { with } 66.7 \mathrm{ml} \text {, of } \\
\text { distilled water. Repeated for } 2 \mathrm{~h} \text { at } 4^{\circ} \mathrm{C} \text {. Extracts combined }\end{array}$ & $24 ; 2$ & 0.0 & 0.0 \\
\hline 10. & $\begin{array}{l}\text { Acetone extract; } 24 \mathrm{~h} \text { extraction at } 4{ }^{\circ} \mathrm{C} \text { with } 70 \mathrm{ml} \text { of } 90 \% \\
\text { acetone }\end{array}$ & $24 ; 2$ & 0.0 & 0.0 \\
\hline 11. & $\begin{array}{l}\text { Phosphate buffer extract; phytoplankton cells with } 100 \mathrm{ml} \text { of } \\
0.05 \mathrm{M} \text { phosphate buffer }\left(0.1 \mathrm{M} \mathrm{KH}_{2} \mathrm{PO}_{4} \text { and } 0.1 \mathrm{M} \mathrm{K}_{2} \mathrm{HPO}_{4}\right) \text {, } \\
\text { frozen }\left(-10^{\circ} \mathrm{C}\right) \text { and thawed }\left(4^{\circ} \mathrm{C}\right) \text { twice. Total extraction time } \\
24 \mathrm{~h}\end{array}$ & $12 ; 1$ & 0.0 & 0.0 \\
\hline 12. & $\begin{array}{l}\text { Acid extract; extraction with } 66.7 \mathrm{ml} \text { of dilute } \mathrm{HCI} \text { (maintained } \\
\text { at pH 2.0), first for } 5 \mathrm{~min} \text { at } 50^{\circ} \mathrm{C} \text { and then } 25 \mathrm{~min} \text { at } 20^{\circ} \mathrm{C} \text {. } \\
\text { Repeated twice for } 30 \mathrm{~min} \text { at } 20^{\circ} \mathrm{C} \text {. Combined extracts } \\
\text { brought to pH } 7.0 \text { with } \mathrm{NaOH}\end{array}$ & $24 ; 2$ & 0.0 & 0.0 \\
\hline 13. & $\begin{array}{l}\mathrm{Na}_{2} \mathrm{CO}_{3} \text { extract; } 40 \mathrm{~min} \text { extraction at } 50^{\circ} \mathrm{C} \text { with } 93.3 \mathrm{ml} \text { of } \\
0.5 \% \mathrm{Na}_{2} \mathrm{CO}_{3} \text {, followed by two } 1 \mathrm{~h} \text { extractions at } 20^{\circ} \mathrm{C} \text { with } \\
93.3 \mathrm{ml} \text { of distilled water. Combined extract brought to } \mathrm{pH} 7.0 \\
\text { with } 5 \% \mathrm{HCl}\end{array}$ & $24 ; 2$ & 0.0 & 0.0 \\
\hline 14. & $\begin{array}{l}\mathrm{NaOH} \text { extract; extraction with } 66.7 \mathrm{ml} \text { of } 1 \mathrm{~N} \mathrm{NaOH} \text {. Heated to } \\
65^{\circ} \mathrm{C} \text { and then allowed to cool towards room temperature for } \\
1 \mathrm{~h} \text {. Followed by two } 1 \mathrm{~h} \text { extractions at } 20^{\circ} \mathrm{C} \text { with } 66.7 \mathrm{ml} \text { of } \\
\text { distilled water. Combined extracts brought to pH } 7.0 \text { with } 5 \% \\
\mathrm{HCl}\end{array}$ & $55 ; 4$ & $\begin{array}{c}4.2 \\
(4.2)\end{array}$ & $\begin{array}{r}65.5^{\circ} \\
(52.7)^{\circ}\end{array}$ \\
\hline 15. & Phytoplankton; Phaeodactylum tricornutum (1 equivalent) & $24 ; 2$ & $\begin{array}{c}0.0 \\
(0.0)\end{array}$ & $\begin{array}{r}95.8^{\circ} \\
(66.7)^{\circ}\end{array}$ \\
\hline
\end{tabular}

the spawning) was considered (Table 4). Females spawned significantly faster when exposed to the extract and sperm than when exposed only to the phytoplankton extract (Mann-Whitney test, $\mathrm{p}<0.05$; Expts 5 \& 6). No such differences were observed for males for which the reaction time was similar to that of females treated with extract plus sperm. These results indicate that sperm had a synergistic effect on reaction time of females exposed to phytoplankton crude extracts. 


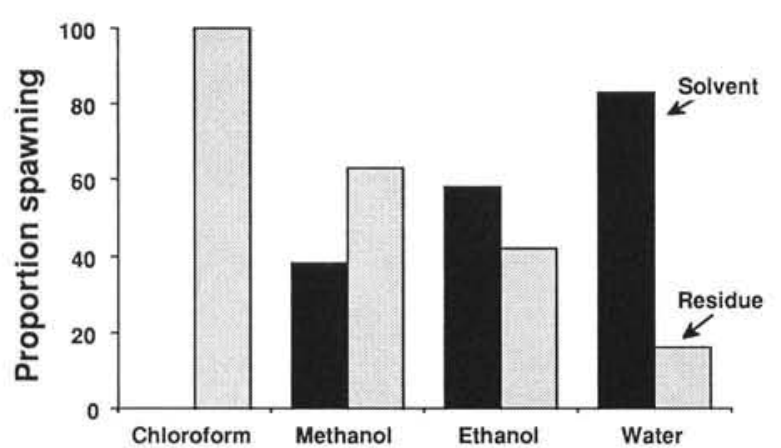

Fig. 1. Proportion of spawning inducer recuperated in the solvent and residual fractions of phytoplankton $\mathrm{NaOH}$ extract which were lyophilized and resuspended in various solvents (see 'Materials and Methods'). The proportions were determined from the spawning response of the sea urchin and each spawning test involved 12 sea urchins and was repeated twice. We used the pooled data since differences between replicates were not significant. Controls for each solubility test were performed using the $\mathrm{NaOH}$ extract of filters without phytoplankton. All control tests showed less than $5 \%$ spawning

Table 2. Molecular weight of the spawning inducer involved in the $\mathrm{NaOH}$ extract of the diatom Phaeodactylum tricornutum. Each bioassay involved 12 sea urchins and was repeated twice. Percent spawning was determined from pooled data since there were no significant differences between replicates

\begin{tabular}{|c|c|c|}
\hline $\begin{array}{l}\text { Expt } \\
\text { no. }\end{array}$ & Treatment & $\begin{array}{c}\text { Spawning } \\
(\%)\end{array}$ \\
\hline
\end{tabular}

1. Extract held at $20^{\circ} \mathrm{C}$ in darkness for $36 \mathrm{~h} \quad 50.0^{\circ}$ in dialysis tubing with MW cutoff of 1200 daltons

2. Extract held at $20^{\circ} \mathrm{C}$ in darkness for $36 \mathrm{~h}$ in dialysis tubing with MW cutoff of 3500 daltons

3. Extract held at $20^{\circ} \mathrm{C}$ in darkness for $36 \mathrm{~h}$ in dialysis tubing with MW cutoff of 6000 to 8000 daltons

4. Extract held at $20^{\circ} \mathrm{C}$ in darkness for $36 \mathrm{~h} \quad 50.0^{\circ}$

5. Extract tested immediately $50.0^{\circ}$

6. Control extract (extraction without phy- 0.0 toplankton)

- Significantly different (Fisher's exact test with Bonferroni correction to the probabilities; $p<0.05$ ) from response of urchins exposed to control extract

\section{Partial purification of spawning inducer}

Attempts were made to purify the spawning inducer using bioassays of sea urchins spawning to guide the purification process (Fig. 4). To remove many nonreactive substances, including proteins, carbohydrates, uronic acids and photosynthetic pigments, 3 pre-extractions were performed on phytoplankton cells prior to alkaline hydrolysis. Extractions were made sequentially

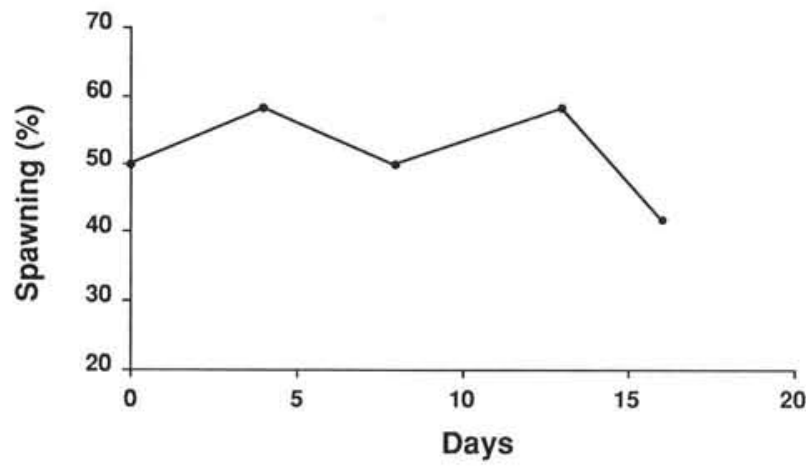

Fig. 2. Strongylocentrotus droebachiensis. Efficiency of the spawning inducer $(\mathrm{NaOH}$ extract from the diatom Phaeodactylum tricornutum), stored in dark at $5{ }^{\circ} \mathrm{C}$, over time. Each point represents the spawning response for 12 sea urchins

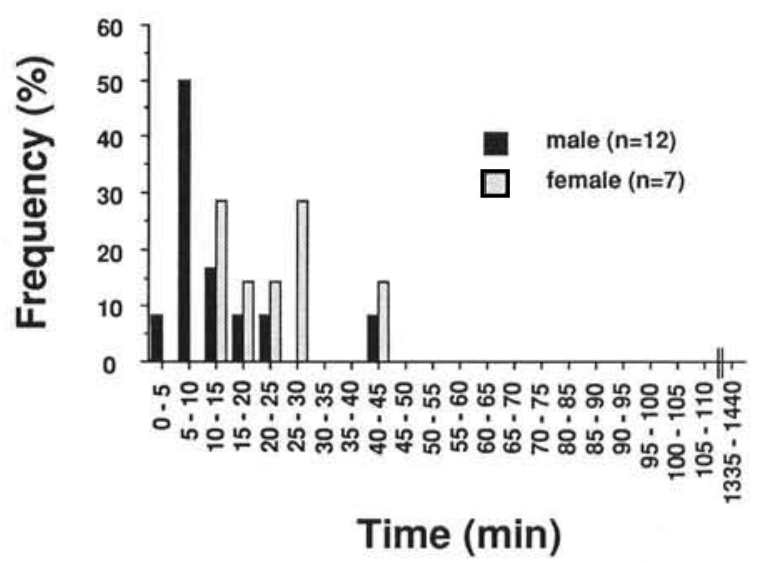

Fig. 3. Strongylocentrotus droebachiensis. Spawning frequency, at 5 min intervals over $1 \mathrm{~d}$, of sea urchins exposed to a 1 equivalent concentration of phytoplankton $\mathrm{NaOH}$ extract

Table 3. Strongylocentrotus droebachiensis. Spawning response of sea urchins exposed in $\mathrm{NaOH}$ extracts from Fucus vesiculosus and Phaeodactylum tricornutum. Each bioassay involved 12 sea urchins and was repeated twice. Percent spawning was determined from pooled data since there were no significant differences between replicates

\begin{tabular}{|c|c|c|c|}
\hline \multirow{2}{*}{$\begin{array}{l}\text { Expt } \\
\text { no. }\end{array}$} & \multirow[t]{2}{*}{ Concentration } & \multicolumn{2}{|c|}{ Spawning (\%) } \\
\hline & & Control & Extract \\
\hline \multicolumn{4}{|c|}{ Fucus vesiculosus } \\
\hline 1. & 0.8 equivalents & 0.0 & $33.3 \cdots$ \\
\hline 2. & 1.6 equivalents & 0.0 & $41.7^{\cdots}$ \\
\hline 3. & 3.2 equivalents & 0.0 & $25.0^{\circ}$ \\
\hline \multirow[t]{2}{*}{4.} & 4.8 equivalents & 0.0 & $33.3^{*}$ \\
\hline & Phaeodactylu & rnutum & \\
\hline 5. & 0.5 equivalents & 0.0 & $41.7^{*}$ \\
\hline 6. & 1.0 equivalents & 0.0 & $66.7^{\cdots}$ \\
\hline \multicolumn{4}{|c|}{$\begin{array}{l}\text { - Significantly different (Fisher's exact test) at the } 0.1 \text { leve } \\
\text { from the response of urchins exposed to control test } \\
\text { - Significantly different at the } 0.05 \text { level }\end{array}$} \\
\hline
\end{tabular}


Table 4. Strongylocentrotus droebachiensis. Percentage spawning and reaction time of male and female sea urchins exposed to spawning males and phytoplankton $\mathrm{NaOH}$ extract, separately and together. Controls consisted of sea urchins exposed to extracts from filters without phytoplankton ( $\mathrm{NaOH}$ extract control). Experiments ran for $2 \mathrm{~h}$. The number of individuals tested in each experimental group was 68

\begin{tabular}{|c|c|c|c|c|}
\hline \multirow[t]{2}{*}{$\begin{array}{l}\text { Expt } \\
\text { no. }\end{array}$} & \multirow[t]{2}{*}{ Treatment } & \multirow[t]{2}{*}{$\begin{array}{c}\text { Spawning } \\
(\%)\end{array}$} & \multicolumn{2}{|c|}{$\begin{array}{c}\text { Mean reaction time }(\mathrm{min})^{a} \\
\left(\mathrm{SD}_{i} \mathrm{n}\right)\end{array}$} \\
\hline & & & Females & Males \\
\hline 1. & Sea water & 2.9 & & \\
\hline 2. & $\begin{array}{l}\mathrm{NaOH} \text { extract control } \\
\text { (conc. } 0.5 \text { equivalent) }\end{array}$ & 0.0 & & \\
\hline 3. & $\begin{array}{l}\mathrm{NaOH} \text { extract control } \\
\text { (conc.: } 1 \text { equivalent) }\end{array}$ & 0.0 & & \\
\hline 4. & Sperm & 0.0 & & \\
\hline 5. & $\begin{array}{l}\mathrm{NaOH} \text { extract } \\
\text { (conc. } 0.5 \text { equivalent) }\end{array}$ & $29.4^{\circ}$ & $\begin{array}{l}23.52^{\mathrm{a}} \\
(9.65 ; 7)\end{array}$ & $\begin{array}{c}12.93^{\mathrm{b}} \\
(10.54 ; 7)\end{array}$ \\
\hline 6. & $\begin{array}{l}\text { Sperm }+\mathrm{NaOH} \text { extract } \\
\text { (conc.: } 0.5 \text { equivalent) }\end{array}$ & $30.9^{\circ}$ & $\begin{array}{l}14.52^{\mathrm{b}} \\
(6.27 ; 8)\end{array}$ & $\begin{array}{c}11.81^{\mathrm{b}} \\
(8.30 ; 14)\end{array}$ \\
\hline 7. & $\begin{array}{l}\mathrm{NaOH} \text { extract } \\
\text { (conc.: } 1 \text { equivalent) }\end{array}$ & $47.0^{\circ}$ & & \\
\hline
\end{tabular}

with (1) distilled water, (2) chloroform/methanol and (3) $\mathrm{Na}_{2} \mathrm{CO}_{3}$, each time retaining the residue. At each step, the supernatant showed little activity. The $\mathrm{NaOH}$ extract obtained from these pre-extracted cells retained a high capacity for spawning induction (45.8\% ; Fig. 4).

Proteins were the major component of this $\mathrm{NaOH}$ extract (21.3 mg phytoplankton equivalent ${ }^{-1}$ ). Adjusting this extract to $\mathrm{pH} 7.0$ caused considerable precipitation. The precipitate was removed by filtration. Large molecules in the filtrate were removed by ultrafiltration with Amicon YM5 membranes with a nominal cutoff at 5000 daltons. The ultrafiltrate did not show reduced induction of spawning compared to the initial $\mathrm{NaOH}$ extract (Fig. 4). This was consistent with the molecular weight estimations from dialysis.

The ultrafiltrate contained substances soluble in organic solvents which were probably liberated by alkaline hydrolysis. To determine whether the spawning inducer could be extracted with organic solvents following alkaline hydrolysis, subsequent extractions were performed directly on $\mathrm{NaOH}$ extracts of phytoplankton cells without the above 3 pre-extraction steps and ultrafiltration (Fig. 5). Extracts obtained with hexane at $\mathrm{pH} 8.0$ (for steroids) failed to induce spawning (Expt 4), whereas extracts obtained with ether at pH 2.0 gave a high spawning response (Expt 6). No spawning activity occurred in control experiments in which organic solvents were applied to the $\mathrm{NaOH}$ extract from filters without phytoplankton (Expts $3 \& 5$ ). This indicated that the spawning inducer could be extracted with ether following alkaline hydrolysis.
The following purification steps were applied to the $\mathrm{NaOH}$ extract after pre-extraction and ultrafiltration (Fig. 4). This ether-purified fraction was yellowish in colour, contained few carbohydrates and proteins, $1.7 \mu \mathrm{g}$ and $2.0 \mu \mathrm{g}$ phytoplankton equivalent ${ }^{-1}$, respectively (compared to 31.3 and $57.4 \mathrm{mg}_{\text {equivalent }}{ }^{-1}$, respectively, for the phytoplankton cells). Furthermore, this fraction showed a strong UV absorption, indicating the presence of aromatic compounds (Fig. 6). In ether (1.4 $\mathrm{ml}$ phytoplankton equivalent ${ }^{-1}$ ), it had absorption peaks at 238, 260 to 266 and $272 \mathrm{~nm}$, a shoulder at $274 \mathrm{~nm}$ and 2 weaker absorption peaks in the visible range at 404 to 416 and $668 \mathrm{~nm}$ (Fig. 6). When the ether extract was evaporated and redissolved in absolute ethanol ( $5 \mathrm{ml}$ phytoplankton equivalent ${ }^{-1}$ ), absorption peaks were observed at 210, 260 to 266 and $274 \mathrm{~nm}$. When redissolved in petroleum ether $\left(35\right.$ to $60{ }^{\circ} \mathrm{C}, 5 \mathrm{ml}$ phytoplankton equivalent ${ }^{-1}$ ), absorption peaks were observed at $217,246,260$ to $266,274 \mathrm{~nm}$. The strong UV absorption disappeared completely in $100 \%$ chloroform indicating that the substance was insoluble in chloroform before and after alkaline hydrolysis. The latter corroborated our previous observation that the spawning inducer was insoluble in chloroform (Fig. 1).

When a large amount of the ether-soluble fraction was applied to cellulose Mn 300 TLC plates and chromatographed using 1-butanol-acetic acid-distilled water (4:1:5, top layer), a yellowish band migrated in front of the solvent. This band absorbed light in the UV range. No other UV-absorbing bands were detected, suggesting that the yellow pigment(s) was responsible 


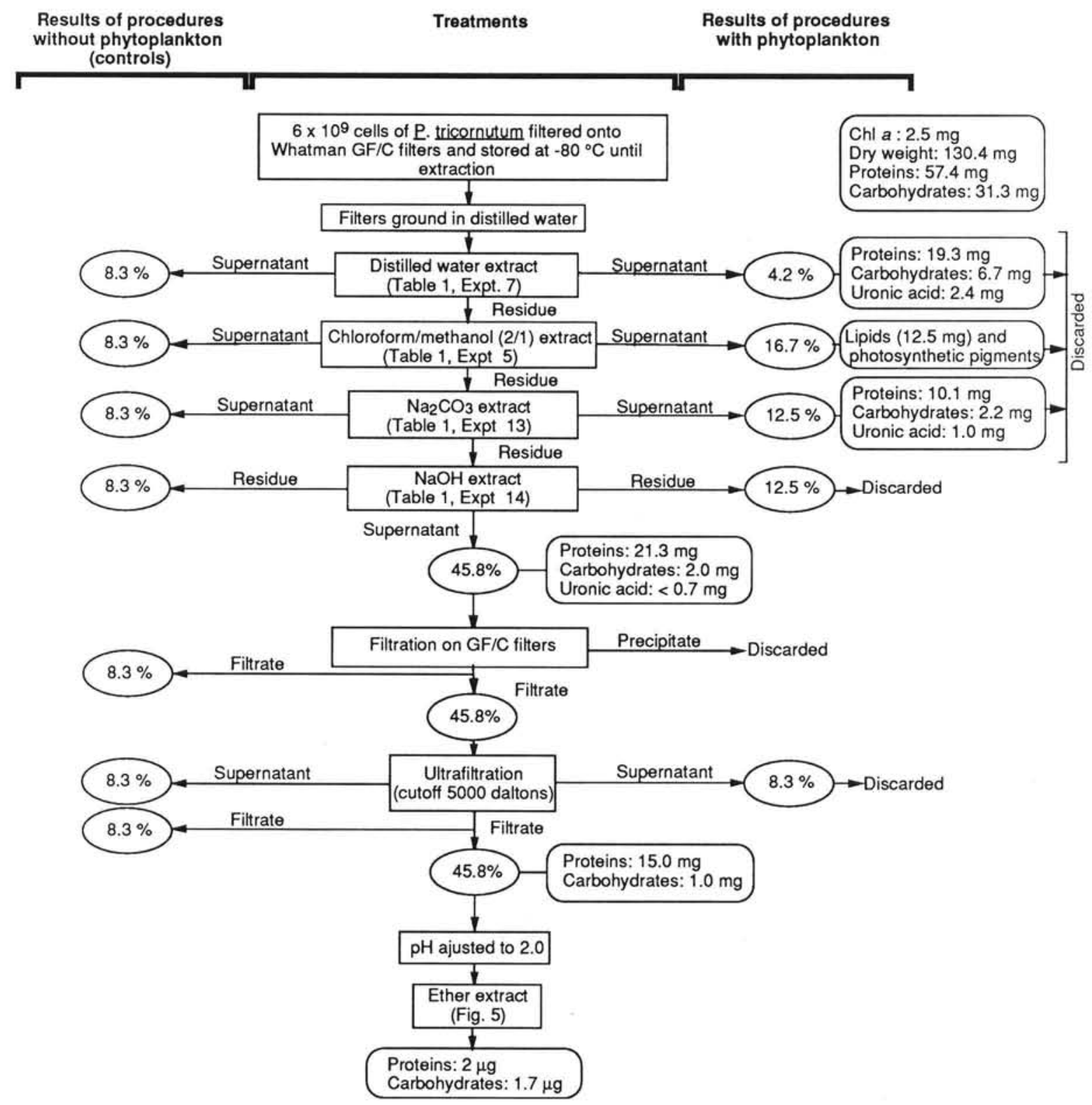

Fig. 4. Flow chart showing partial purification of the spawning inducer produced by the diatom Phaeodactylum tricornutum. Spawning responses $(\%)$ of the sea urchin Strongylocentrotus droebachiensis are indicated for each purification step. Each experiment involved 12 sea urchins and was repeated twice. Concentrations of metabolites are expressed in weight phytoplankton equivalent ${ }^{-1}$. Figures and tables describing the experiments in more detail are indicated in parentheses

for this strong absorption. When chromatograms were sprayed with a mixture of equal volumes of $1 \%$ ferric chloride and $1 \%$ potassium ferricyanide, for detection of phenols (Harborne 1973), only this band reacted.

\section{DISCUSSION}

\section{The potential spawning inducer}

Substances released by various species of phytoplankton trigger spawning in green sea urchins (Starr et al. 1990). Taxonomically diverse algae liberate simple and complex carbohydrates during active growth and these may account for a considerable fraction of their photoassimilated carbon (Handa 1970, Myklestad \& Haug 1972, Hellebust 1974, Bolze \& Soeder 1978, Eberlein et al. 1983). Amino acids and peptides are released, but they represent only a small fraction ( 1 to $12 \%$ ) of the total extracellular material (Hellebust 1974). Proteins and carbohydrates represent 44 and $24 \%$, respectively, of the dry weight of Phaeodactylum tricornutum cells. These values are similar to those 
Fig. 5. Flow chart showing extraction techniques applied to $\mathrm{NaOH}$ phytoplankton extract using organic solvents and percentage spawning obtained when sea urchins were exposed to each extract. In the control experiments, organic solvents were applied to a $\mathrm{NaOH}$ extract of filters without phytoplankton. Each bioassay involved 12 sea urchins and was repeated twice. We used the pooled data as differences between replicates were not significant. Tests marked with an asterisk ( $\left.{ }^{\circ}\right)$ were significantly different (Fisher's exact test; $\mathrm{p}<0.05$ ) from the respective controls

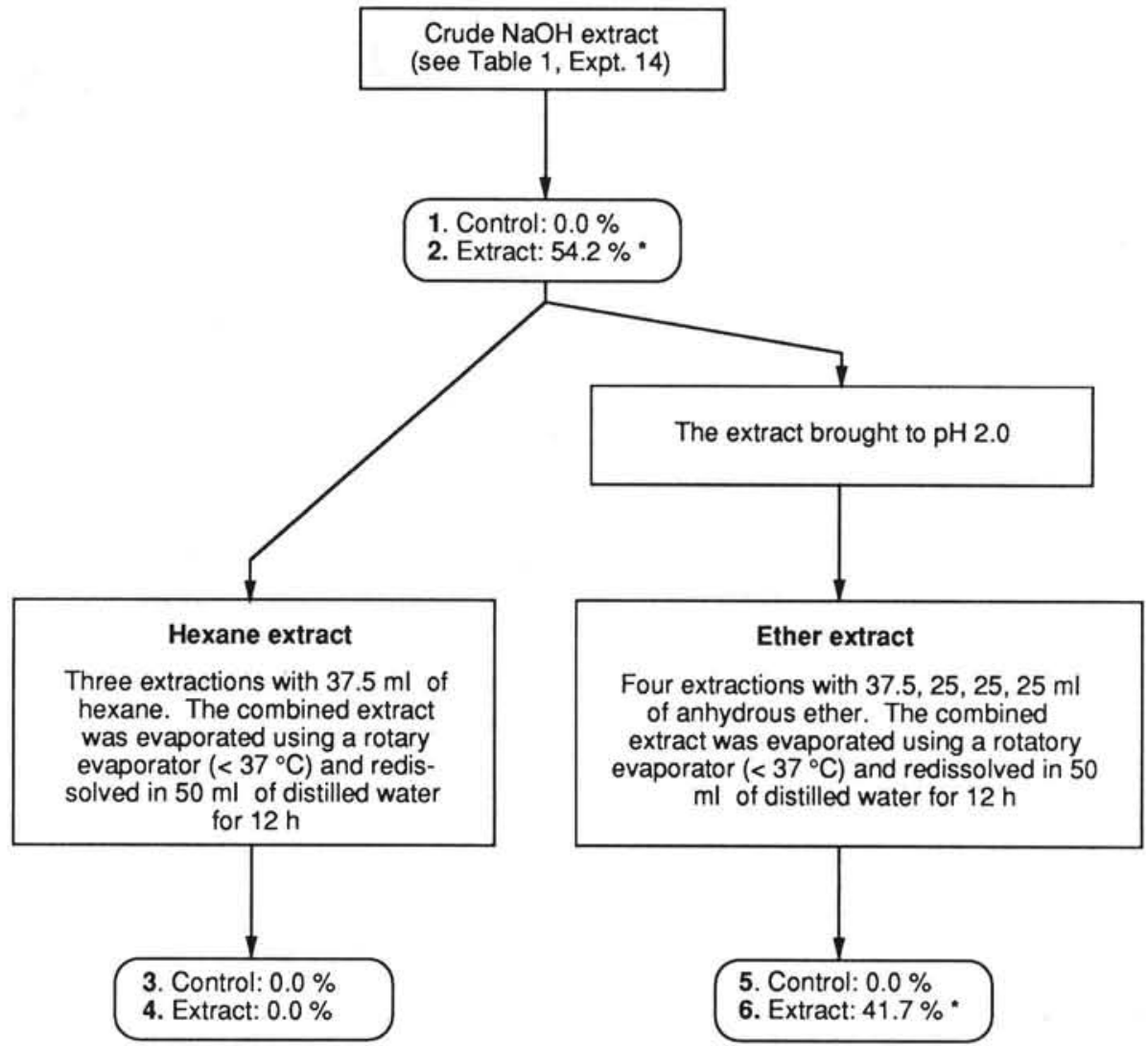

given by Parsons et al. (1961) for P. tricornutum and several other classes of unicellular marine algae. In the ether-purified fraction (obtained after pre-extraction, alkaline hydrolysis and ultrafiltration) with which the spawning activity is associated, the carbohydrate and protein concentrations are low, representing only $1.3 \times$ $10^{-5}$ and $1.5 \times 10^{-5} \%$ of the dry weight of the cells, respectively ( 2 and $1.7 \mu$ g phytoplankton equivalent ${ }^{-1}$ ). Thus, the spawning inducer does not appear to be either a carbohydrate or a protein. Similarly, chloroform/methanol and benzene/methanol extracts of $P$. tricornutum cells fail to remove the spawning inducer, suggesting that the inducer is not a lipid.

On the other hand, the aromatic absorption peaks seen in the ultraviolet spectrum of the ether-purified fraction seem to be due to a yellowish phenolic compound(s). This UV-absorbing material is similar to the spawning inducer since it is at least partially soluble in ethanol and insoluble or unstable in chloroform. Furthermore, the spectral absorption peak of this metabolite at 260 to $266 \mathrm{~nm}$ is similar to that of yellow UVabsorbing substances released by a variety of phytoplankton and macroalgae (Fig. 7; Fogg \& Boalch 1958, Yentsch \& Reichert 1962, Craigie \& McLachlan 1964, Sieburth 1968, 1969, Sieburth \& Jensen 1969, Kroes 1970, Indelicato 1985) and to the Gelbstoff fraction in sea water (Bricaud et al. 1981, Carder et al. 1989). This agrees with the observations of Starr et al. (1990) indicating that various species of phytoplankton release the spawning inducer, and with the present data showing that the inducer may occur in the macroalga Fucus vesiculosus. Thus, the UV-absorbing compound isolated in our ether extract appears to be the spawning inducer. However, spawning in nature does not correlate with the abundance of Gelbstoff (yellow substances), since Gelbstoff is largely associated with land drainage (James \& Birge 1938, Jerlov 1955, Kalle 1966 , Hojerslev 1974, Stuermer 1975, Lundgren 1976, Bricaud et al. 1981) and spawning in the St. Lawrence Estuary occurs after the period of major runoff (Starr 1990), thus probably after the Gelbstoff peak. Sieburth \& Jensen (1969) indicate that yellow UV-absorbing substances are formed from phenol-like precursors released by $F$. vesiculosus which are colourless and less absorbing in UV light ( $270 \mathrm{~nm})$. Under the alkaline conditions of the sea, these precursors react with proteins and carbohydrates to form yellow-coloured phenolic complexes which are similar to Gelbstoff. They suggested that such complexes of macroalgal origin can make up a considerable part of the marine Gelbstoff, eventually forming larger complexes which precipitate as organic aggregates. The formation of phenolic complexes 


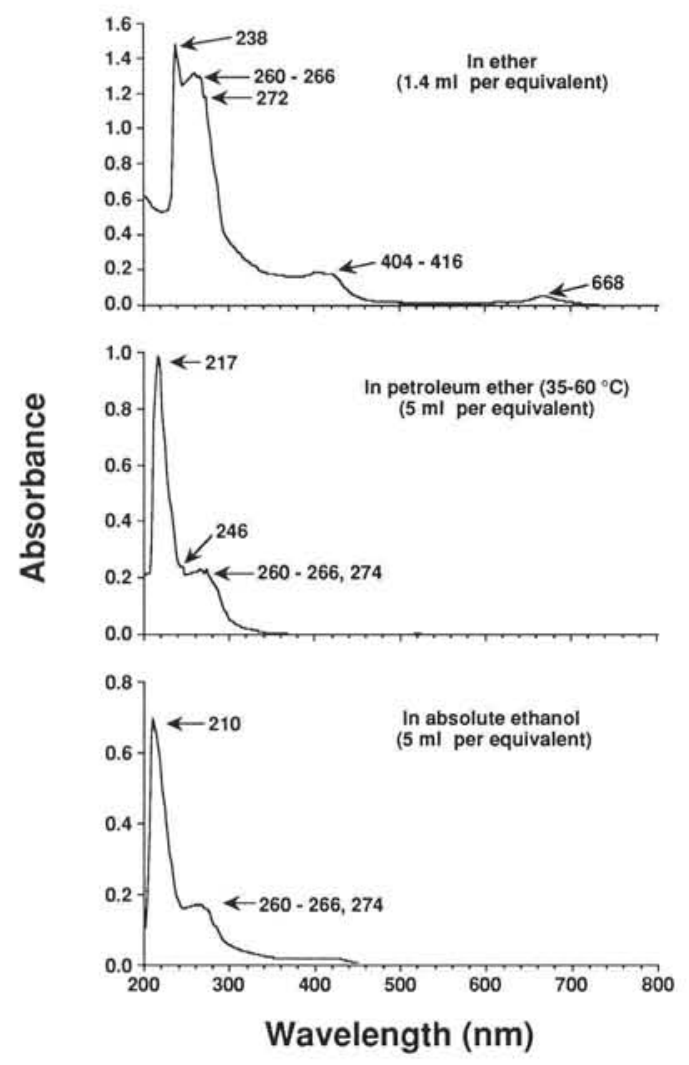

Fig. 6. Absorption spectra of the ether-purified fraction obtained from the diatom Phaeodactylum tricornutum, in ether, petroleum ether and absolute ethanol. A light path of $1 \mathrm{~cm}$ was employed and in all cases blank extracts were substracted

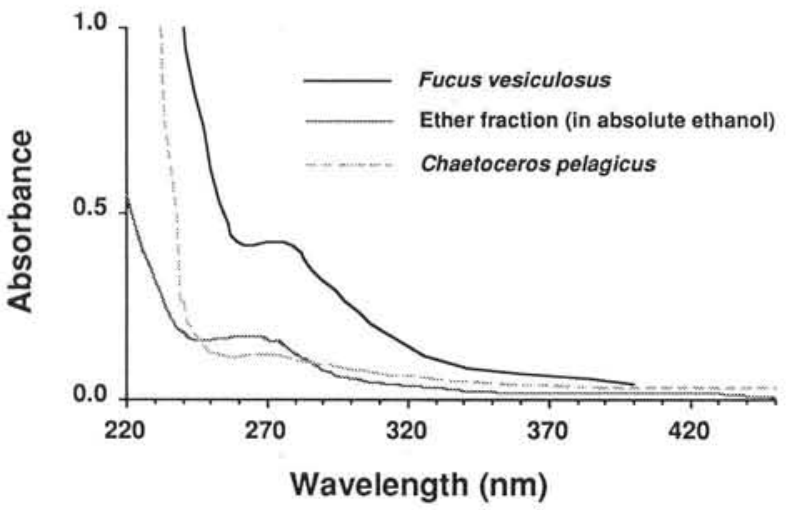

Fig. 7. Comparison of the absorption spectra of the etherpurified extract obtained from Phaeodactylum tricornutum with spectra of the yellow UV-absorbing substances released by Chaetoceros pelagicus [from Yentsch \& Reichert (1961)] and Fucus vesiculosus [from Craigie \& McLachlan (1963)]

occurs only under alkaline conditions and the phenolic precursors may be oxidized before or after reaction with proteins and carbohydrates.

The loss of activity of the inducer in the culture filtrate (Starr et al. 1990) and in the present bioassays with the
$\mathrm{NaOH}$ extract could be explained by modifications of the inducer similar to those which Sieburth \& Jensen (1969) observed for Gelbstoff precursors in alkaline seawater. The stability of the inducer at neutral $\mathrm{pH}$ could be explained by the fact that phenolic complexes are only formed under alkaline $\mathrm{pH}$. A more rapid transformation of phenol-like precursors to phenolic complexes is expected as the concentration of precursors increases (Haslam 1988 describes mechanisms for the aggregation and precipitation of protein-phenol complexes). The decrease in rate of loss of spawning activity of phytoplankton culture filtrates with time (Starr et al. 1990) supports the hypothesis that a phenolic pigment related to Gelbstoff is responsible for spawning.

Phenolic compounds in plant tissues are usually combined with sugars as glycosides and, upon hydrolysis, a number of ether-soluble phenolic substances are released (Harborne 1973). In the phytoplankton cells, the spawning inducer is probably bound to macromolecules, since it cannot be extracted directly with either ethanol or ether, but is soluble in ether and has an increased solubility in ethanol after alkaline hydrolysis.

The possible advantage of such a compound as a spawning cue is that the modification of released phenolic compounds should result in a signal of short duration, and, therefore, the cue should have a high signal-to-noise ratio. Thus, it should accurately indicate the presence of phytoplankton.

\section{Contribution of benthic seaweeds to spawning cue}

The present study showing the presence of a spawning inducer in Fucus vesiculosus indicates that macroalgae may also contribute to natural spawning. This could disrupt the coupling of the planktotrophic larval phase of species such as the sea urchin with an abundance of their primary food source, phytoplankton (Starr et al. 1990). Although phenolic materials from macroalgal can make up a large fraction of UVabsorbing materials in temperate coastal waters (Carlson \& Mayer 1983), the close correlation of spawning with the spring phytoplankton bloom (Himmelman 1981, Starr 1990) strongly suggests that inducer originates from phytoplankton rather than macroalgae. This hypothesis is further suggested because the excretion by macroalgae decreases with temperature (Carlson \& Mayer 1983) and water temperatures are low during the spring bloom. An alternative and complementary hypothesis is that the inducer from macroalgae is different and less effective than that from phytoplankton. In fact, our data indicates that extract from $F$. vesiculosus induces less spawning than that from Phaeodactylum tricornutum. Thus, we consider that the major source of substances triggering natural 
spawning is from the rapid growth of phytoplankton. Nevertheless, further work is required to identify the various sources of the spawning inducers, and to determine their relationship with the types of substances which we isolated in the laboratory.

\section{Synergistic effect of sperm}

Successful fertilization is critical for marine invertebrates which release their gametes into the water (Mortensen 1938, Thorson 1946, Chia 1974, Pennington 1985, Levitan 1988, Denny \& Shibata 1989). Pennington (1985) has shown that sea urchin sperm is only viable for a short period ( $<20 \mathrm{~min}$ ) and that successful fertilization requires high sperm densities $\left(>10^{6}\right.$ sperm $\left.\mathrm{l}^{-1}\right)$. These observations emphasize the importance of synchronous spawning within populations. Photoperiod, which varies in a regular annual cycle, is probably a good proximal signal to coordinate the prolonged process of gamete production (Pearse et al. 1986). However, shortterm changes, such as a phytoplankton outburst, are probably much more favourable as spawning signals. The spring phytoplankton bloom is one of the most sharply defined events in temperate and polar seas. The synchrony of spawning may further be enhanced because gametes, or pheromones released with gametes, induce spawning (Gemmill 1914, 1920, Fox 1924, Mac Ginite \& Mac Ginite 1949, Hyman 1955, Rothschild 1956, Lewis 1958, Reese 1966, Kennedy \& Pearse 1975, Himmelman 1981, Iliffe \& Pearse 1982, Starr et al. 1990). Nevertheless, some workers have been unable to stimulate spawning using gametes from conspecifics (Gemmill 1900, Palmer 1937, Pennington 1985). High sperm concentrations stimulated spawning in the sea urchin Strongylocentrotus droebachiensis, but only after a period of $2 \mathrm{~d}$ or more (Starr et al. 1990). Sperm failed to induce spawning in our experiments lasting only $2 \mathrm{~h}$, but it did increases the speed of the spawning response of females exposed to the phytoplankton inducer. Thus, an unknown metabolite in the sperm suspension may act as a modulator enhancing spawning. By definition, modulators have no effect at natural concentrations in the absence of the cue (Rittschof \& Bonaventura 1986). This seems to be the case for sperm suspension. In nature, we expect that phytoplankton induces spawning in the most receptive males and their gametes, together with phytoplankton, stimulate subsequent massive spawning.

\section{New technique for obtaining gametes in mariculture}

In invertebrate mariculture, easily executed techniques are needed to induce heavy and synchronous gamete release. The use of a natural signal should be more favourable than the use of chemicals such as hydrogen peroxide and $\mathrm{KCl}$ which may damage gametes and embryos. Phytoplankton provides a reliable method for the induction of spawning. Phytoplankton is probably the natural spawning cue in many marine invertebrates (Starr et al. 1990) and the identification of the inducer(s) produced by phytoplankton could permit its use in controlling spawning without culturing large amounts of algae.

Acknowledgements. We are greatly indebted to S. Gosselin, P. DeKonink and T. Duchêne for their competent assistance in the laboratory and to Drs J.-X. Garneau, D. Rittschof, G. Rosenberg, H. Guderley, J. McNeil and J. Hellebust for discussions and comments on the manuscript. The research was funded by NSERC and Fisheries and Oceans grants to J. H. Himmelman, by Department of Fisheries and Oceans operating funds to J.-C. Therriault, and by FCAR and NSERC funding to GIROQ. The first author was supported by scholarships from NSERC and FCAR.

\section{LITERATURE CITED}

Bitter, T., H., Muir, M. (1962). A modified uronic acid carbazole reaction. Analyt. Biochem. 4: 330-334

Bohlen, P., Stein, S., Dairman, W., Udenfriend, S. (1973). Fluorometric assay of proteins in the nanogram range. Arch. Biochem. Biophys. 155: 213-220

Bolze, A., Soeder, C. J. (1978). Konzentrationsänderungen der extrazellulären organischen Substanz bei Synchronkulturen von Scenedesmus acutus var. alternans Hortob. Arch. Hydrobiol. 82: 142-154

Bricaud, A., Morel, A., Prieur, L. (1981). Absorption by dissolved organic matter of the sea (yellow substance) in the UV and visible domains. Limnol. Oceanogr. 26: 43-53

Carder, K. L., Steward, R. G., Harvey, G. R., Ortner, P. B. (1989). Marine humic and fulvic acids: their effects on remote sensing of ocean chlorophyll. Limnol. Oceanogr. 34: $68-81$

Carlson, D. J., Mayer L. M. (1983). Relative influence of riverine macroalgal phenolic materials on UV absorbance in temperate coastal waters. Can. J. Fish. Aquat. Sci. 40: 1258-1263

Chia, F. S. (1974). Classification and adaptive significance of developmental patterns in marine invertebrates. Thalassia jugosl. 10: 321-339

Chrost, R. J., Faust, M. A. (1983). Organic carbon release by phytoplankton: its composition and utilization by bacterioplankton. J. Plankton Res. 5: 477-493

Craigie, J. S., McLachlan, J. (1964). Excretion of coloured ultraviolet absorbing substances by marine algae. Can. J. Bot. 42: 23-33

Denny, M. W., Shibata, M. F. (1989). Consequences of surfzone turbulence for settlement and external fertilization. Am. Nat. 134: 859-889

Dubois, M., Gilles, K. A., Hamilton, J. K., Rebers, P. A., Smith, F. (1956). Calorimetric method for determination of sugars and related substances. Anal. Chem. 28: 350-356

Eberlein, K., Brockmann, U. H., Hammer, K. D., Katter, G., Laake, M. (1983). Total dissolved carbohydrates in an enclosure experiment with unialgal Skeletonema costatum culture. Mar. Ecol. Prog. Ser. 14: 45-58 
Falk-Petersen, I. B. (1982). Ecological investigations on the zooplankton community of Balsjorden, northern Norway: planktonic eggs and larvae from March 1978 to February 1980. Sarsia 67: 69-78

Fogg, G. E. (1983). The ecological significance of extracellular products of phytoplankton photosynthesis. Botanica mar. 26: $3-14$

Fogg, G., Boalch, G. T. (1958). Extracellular products in pure cultures of brown alga. Nature, Lond. 181: 789-790

Giese, A. C., Kanatani, H. (1987). Maturation and spawning. In: Giese, A. C., Pearse, J. S., Pearse, V. B. (eds.) Reproduction of marine invertebrates, Vol. IX, General aspects: seeking unity in diversity. Blackwell Scientific Publications/The Boxwood Press, Palo Alto/Pacific Grove, p. 251-329

Fox, H. M. (1924). The spawning of echinoids. Proc. camb. Phil. Soc. biol. Sci. 1: 71-74

Gemmill, J. F. (1900). On the vitality of ova and spermatozoa of certain animals. J. Anat. Physiol. 34: 163-181

Gemmill, J. F. (1914). The development and certain points in the adult structure of Asterias rubens. Phil. Trans. R. Soc. 205B: $213-294$

Gemmill, J. F. (1920). The development of the starfish Crossaster papposus, Müller and Troschel. Q. J. microsc. Sci. 64: $155-189$

Guillard, R. R. L., Ryther, J. H. (1962). Studies of marine planktonic diatoms. 1. Cyclotella nana Hustedt and Detonula confervacea (Cleve) Gran. Can. J. Microbiol. 8: 229-239

Handa, N. (1970). Dissolved and particulate carbohydrates. In: Hood, D. W. (ed.) Organic matter in natural waters. Inst. Mar. Sci., Fairbanks, AK, p. 129-152

Harborne, J. B. (1973). Phytochemical methods. Chapman and Hall, London

Haslam, E. (1988). Plant polyphenols (syn. Vegetable tannins) and chemical defense - A reappraisal. J. Chem. Ecol. 14 $1789-1805$

Hellebust, J. A. (1974). Extracellular products. In: Stewart, W. D. P. (eds.), Algal physiology and biochemistry. Blackwell Scientific Publications, Palo Alto, p. 838-863

Himmelman, J. H. (1975). Phytoplankton as a stimulus for spawning in three marine invertebrates. J. Exp. Mar. Biol. Ecol. 20: 199-214

Himmelman, J. H. (1981). Synchronization of spawning of marine invertebrates by phytoplankton. In: Clark, W. J. Jr., Adams, T. S. (eds.) Advances in invertebrate reproduction. Elsevier/North Holland, New York, p. 1-19

Hojerslev, N. K. (1974). Inherent and apparent optical properties of the Baltic. Univ. Copenhagen Inst. Phys. Oceanogr. Rep. No 23

Hyman, L. H. (1955). The invertebrates. Vol. IV. Echinodermata, the coelomate bilateria. McGraw-Hill, New York

Iliffe, T. M., Pearse, J. S. (1982). Annual and lunar reproductive rhythms of the sea urchin, Diadema antillarum (Philippi) in Bermuda. Int. J. Invert. Repr. 5: 139-148

Indelicato, S. R. (1985). The release of water soluble colored compounds by a marine dinoflagellate. J. Phycol. 20 (suppl.): 18

James, H. R., Birge, E. A. (1938). A laboratory study of the absorption of light by lake waters. Trans. Wis. Acad. Sci. Arts Lett. 31: 1-154

Jerlov, N. G. (1955). Factors influencing the transparency of Baltic waters. Meddn. oceanogr. Inst. Göteborg, No. 25

Kalle, K. (1966). The problem of Gelbstoff in the sea. Oceanogr. mar. Biol. Ann. Rev. 4: 91-104

Kennedy, B., Pearse, J. S. (1975). Lunar synchronization of the monthly reproductive rhythm in the sea urchin Centros- phanus coronatus Verrill. J. exp, mar. Biol. Ecol. 8: $167-186$

Kochert, G. (1978). Quantitation of macromolecular components of microalgae. In: Hellebust, J. A., Craigie, J. S. (eds.) Handbook of phycological methods, physiological and biochemical methods. Cambridge University Press, Cambridge, p. 189-195

Kroes, H. W. (1970). Excretion of mucillage and yellow-brown substances by some brown algae from the intertidal zone. Botanica mar. 13: 107-110

Levitan, D. R. (1988). Asynchronous spawning and aggregative behavior in the sea urchin Diadema antillarum (Philippi). In: Burke, R. D., Mladenov, P. V., Lambert, P., Parsley, R. L. (eds.) Echinoderm biology. Balkema, Rotterdam, p. 181-186

Lewis, J. B. (1958). The biology of the tropical sea urchin Tripneustes esculentus Leske in Barbados, British West Indies. Can. J. Zool. 36: 607-621

Lewis, W. M. (1986). Evolutionary interpretations of allelochemical interactions in phytoplankton algae. Am. Nat. 127: $184-194$

Lorenzen, L. (1967). Determination of chlorophyll and phaeopigments: spectrophotometric equations. Limnol. Oceanogr. 12: 343-344

Lundgren, B. (1976). Spectral transmittance measurements in the Baltic. Univ. Copenhagen Inst. Phys. Oceanogr. Rep. No. 30

MacGinite, G. E., MacGinite, N. (1949). Natural history of marine animals. McGraw-Hill, New York

Maestrini, S. Y., Bonin, D. J. (1981). Allelopathic relationships between phytoplankton species. In: Platt, T. (ed.) Physiological bases of phytoplankton. Can. Bull. Fish. Aquat. Sci. 210: p 323-338

Mague T. H., Friberg, E., Hughes, D. J., Morris, I. (1980). Extracellular release of carbon by marine phytoplankton: a physiological approach. Limnol. Oceanogr. 25: 262-279

Mortensen T. (1938). Contributions to the study of the development and larval forms of echinoderms. IV. K. Dan. Vidensk. Selsk. Skr. Natvidensk. Math. afd. 9, raekke 7

Myklestad, S., Haug, A. (1972). Production of carbohydrate by the marine diatom Chaetoceros affinis var. Willei (Gran) Hustedt. 1. Effect of the concentration of nutrients in the culture medium. J. exp. mar. Biol. Ecol. 9: 125-136

Myklestad, S., Holm-Hansen, H., Varum, K. M., Volcani, B. E, (1989). Rate of release of extracellular amino acids and carbohydrates from the marine diatom Chaetoceros affinis. J. Plankton Res. 11: 763-773

Nalewajko, C., Schindler, D. W. (1976). Primary production, extracellular release, and heterotrophy in two lakes in the ELA, northwestern Ontario. J. Fish. Res. Bd Can. 33: 219-226

Packard, T. T., Dortch, Q. (1975). Particulate protein-nitrogen in North Altlantic surface waters. Mar. Biol. 33: 347-354

Palmer, L. (1937). The shedding reaction in Arbacia punctulata. Physiol. Zool. 10: 352-367

Parsons, T. R., Stephens, K., Strickland, J. D. H. (1961). On the chemical composition of eleven species of marine phytoplankters. J. Fish. Res. Bd Can. 18: 1001-1016

Pearse, J. S., Eernisse, J. D., Pearse, V. B., Beauchamp, K. A. (1986). Photoperiodic regulation of gametogenesis in sea stars, with evidence for an annual calendar independent of fixed daylength. Am. Zool. 26: 417-431

Pennington, J. T. (1985). The ecology of fertilization of echinoid eggs: the consequences of sperm dilution, adult aggregation, and synchronous spawning. Biol. Bull, mar. biol. Lab., Woods Hole 169: 417-430 
Pintner, I. J., Altmeyer, V. L. (1979). Vitamin $\mathrm{B}_{12}$-binder and other algal inhibitors. J. Phycol. 15: 391-398

Pratt, D. M. (1966). Competition between Skeletonema costatum and Olisthodiscus luteus in Narrangansett Bay and in culture. Limnol. Oceanogr. 11: 447-455

Reese, E. S. (1966). The complex behavior of echinoderms. In: Boolootian, R. A. (ed.) Physiology of Echinodermata. Wiley, New York, p. 157-218

Rittschof, D., Bonaventura, J. (1986). Macromolecular cues in marine systems. J. chem. Ecol. 12: 1013-1023

Rothschild, L. (1956). Fertilization. Methuen, London

Sieburth, J. McN. (1968). Studies on algal substances in the sea. I. Gelbstoff (humic material) in terrestrial and marine waters. J. exp. mar. Biol. Ecol. 2: 174-189

Sieburth, J. McN. (1969). Studies on algal substances in the sea. III. The production of extracellular organic matter by littoral marine algae. J. exp. mar. Biol. Ecol. 3: 290-390

Sieburth, J. McN., Jensen, A. (1969). Studies on algal substances in the sea. II. The formation of Gelbstoff (humic

This article was presented by P. J. Wangersky, Halifax, N.S. Canada material) by exudates of Phaeophyta. J. exp. mar. Biol. Ecol. 3: 275-289

Starr, M. (1990). Mécanismes de coordination entre la ponte de certains invertébreś marins et la poussée printanière du phytoplancton. Ph.D. thesis, Université Laval

Starr, M., Himmelman, J. H., Therriault, J.-C. (1990). Direct coupling of marine invertebrate spawning with phytoplankton blooms. Science 247: 1071-1074

Stuermer, R. H. (1975). The characterization of humic substances in sea water. Ph.D, thesis, Mass. Inst. Technol., Woods Hole Oceanogr. Inst.

Thorson, G. (1946). Reproduction and larval development of Danish marine bottom invertebrates. Meddr Kommn Havunders. Kbh. Ser. Plankton 4: 1-523

Uchida, T. (1977). Excretion of a diatom inhibitory substance by Prorocentrum micans Ehrenberg. Jap. J. Ecol. 27: 1-4

Yentsch, C. S., Reichert, C. A. (1962). The interrelationship between water-soluble yellow substances and chloroplastic pigments in marine algae. Botanica mar. 3: 65-74

Manuscript first received: January 17, 1991

Revised version accepted: December 9, 1991 